\title{
Substance use characteristics, health risk practices and associated factors among people imprisoned in Catalonia: a cross-sectional study
}

\author{
Bañuls-Oncina E ${ }^{1}$, Clua-García $\mathrm{R}^{1,2}$, Imbernón Casas $\mathrm{M}^{1}$, Jiménez-Vinaja $\mathrm{R}^{1}$ \\ ${ }^{1}$ Brians 1 Prison. Sant Esteve Sesrovires. Barcelona. \\ ${ }^{2}$ Facultat de Ciències de la Salut de Manresa. Universitat de Vic-Universitat Central de Catalunya.
}

\begin{abstract}
Introduction: There are gaps in the available kowledge about substance use and risky practices among prison inmates wich we proposed to clarify in order to improve interventions.

Material and method: We conducted a specifically adapted survey with 178 potential users imprisoned in the Brians 1 Prison of Barcelona. We applied a snowball sampling method, with peers as privileged access interviewers, which is particularly recommended to bring out hidden information.

Results: $74.7 \%$ of participants admitted to excessive use of addictive substances throughout their life. In the last 6 months in prison, $75.8 \%$ accepted that they had used drugs, while $18.5 \%$ injected them. $36.4 \%$ of the latter group participated in the needle exchange program (NEP) of the facility and 54.5\% acknowledged that they shared the needles. Spanish people (adjusted odds ratio $[\mathrm{AOR}]=4,79)$, recidivists $(\mathrm{AOR}=2.67)$, penalised individuals $(\mathrm{AOR}=2.70)$ and those involved in serious transgressions of prison regulations $(\mathrm{AOR}=3.01)$ showed greater probability of substance use in prison. $\mathrm{A}$ longer sentence $(\mathrm{AOR}=1.13)$, having undergone treatment for drug problems $(\mathrm{AOR}=3.84)$ and being a carrier of blood-borne infections $(\mathrm{AOR}=3.95)$ were linked to intravenous drug use. Injectors in the NEP were predominantly women $(66.7 \%)$ and were more interested in caring for their health $(90.9 \%)$.

Discussion: The study reveals use of addictive substances and health risk practices among inmates in Catalonian prisons, despite their exposure to prevention policies mainly focused on abstinence; relates health risk behaviours to marginalization processes within the institution, and then consider the need to extend the scope of harm reduction interventions and to reinforce its appeal by incorporating the users' perspectives on the issue.
\end{abstract}

Keywords: drug users, health risk behaviors, substance-related disorders, therapy, social marginalization, prisons, health education.

Text received: 17/05/2018

Text accepted: 26/10/2018

\section{INTRODUCTION}

Prison inmates, in Spain and other Western countries, show a higher prevalence of substance-related disorders (SRD) than those living in the community ${ }^{1,2}$.

In the month before entering prison, future inmates consume alcohol (64.8\%), cannabis (39.8\%), cocaine $(51.1 \%)$, heroin $(13.7 \%)$ and tranquilisers $(13.3 \%)$ in larger amounts than the general public ${ }^{3}$. When these persons enter prison, their consumption changes: it decreases dramatically in intensity, the pro- file of the most frequently used substances changes to the following: cannabis $(21.3 \%)$, tranquilisers $(4.1 \%)$, alcohol $(3.8 \%)$, heroin $(2.4 \%)$ and cocaine $(2.4 \%)$, respectively $^{3}$; and the hazards associated with consumption increases, as it is now associated with health risk practices that lead to infection from blood-borne and sexually transmitted diseases (STBBI), such as injecting $(7 \%$ of new inmates acknowledge that they are intravenous drug users (IDU) ${ }^{4}$ ) and sharing injection equipment, in a population with a high prevalence of infection from the human immunodeficiency virus 
(HIV, 5.1\%) and from hepatitis C (HCV, 6.5\% $\left.\%^{5}\right)$. In fact the use of drugs, especially injected drug use, and sexual intercourse without protection, are the main risk factors for infection from HIV and HCV in prison ${ }^{6-9}$.

Harm reduction is a pragmatic approach geared towards tackling drug consumption and the associated risk behaviours ${ }^{10}$, which, without renouncing the final objective of abstinence ${ }^{11}$, subordinates it to the specific needs and possibilities of the client, respecting their decisions regarding the change, and bringing the treatment closer to the majority of the users that continue to use substances. It has a wide range of strategies, ranging from education in hygienic consumption to work directed towards abstinence, including management of use ${ }^{12}$.

The needle exchange program (NED) is a harm reduction strategy that has shown itself to be especially effective in prisons and in the community. It provides those who wish to inject with access to sterile injection material. It prevents infection from STBBI, reducing the use of contaminated material, and promotes improvements in quality of life amongst users, probably by interiorising self-care strategies ${ }^{13}$.

The available data about substance use and its associated problems in prison have limitations that restrict its application to interventions. Such difficulties are due to the fact that they refer to illegal activities, which leads the inmates to resist giving information about them for fear of negative consequences ${ }^{14}$.

There are effective investigation strategies for outreach to populations that are not easy to access, generally separated from formal care services and at risk, to gather information about their behaviours and hidden needs. All of them involve working with equals ${ }^{15-17}$.

The purpose of this study was to gain greater knowledge about the use of addictive substances and their main corollaries in Brians 1 Prison, including information obtained from specific sampling techniques to reveal hidden practices, thereby increasing their applicability to the design of programs to improve the health of drug users in prison.

The overall objective of the study can be broken down into two specific ones:

- Provide descriptive data about the use of psychoactive substances, related problems and treatment, the associated risk practices and their consequences for the health of inmates in a prison.

- Identify possible factors associated with three core elements, especially representative of the problems analysed: drug use, injected consumption and participation in NEP in prison.

\section{MATERIALS AND METHODS}

The research was inserted into a broader peer health education program based on the project Euro Boule de neige, developed in Belgium by the association Modus Vivendi, geared towards analysing the situation of drug using inmates and towards preventing health problems associated with substance use $\mathrm{e}^{18}$.

The information gathering process was channelled via a survey, based on the Spanish adaptation of the initial project ${ }^{19}$, which was in turn modified to adapt to the specific needs of the population under study, in line with the methodology proposed in the original, in three stages:

- Preparation (in this case, modification) of the survey depending on the research objectives.

- Validation pilot test, carried out on ten users in the population, in which a prototype of the questionnaire was completed to check its suitability, and any necessary changes were then made to create the final version.

- Training of expert users in the effective implementation of the survey. Troughout the peer health educational program, a group of equals, the peer workers, all of them residents in the prison and potentially users, were trained in the administration of the questionnaire, working specially in unifying the interpretation criteria of the answers, management of role conflicts arising from their situation as mediators between users and professionals, and respecting the freedom and privacy of the interviewee ${ }^{18,19}$.

The result of the above process was an information gathering tool for the socio-demographic and prison situation, drug use and risk behaviours, the health situation and the use of services. This was applied in an interview by the co-workers, using a snowball sampling approach with privileged access interviewers. With the snowball method we formed a benchmark group of prisonners, potentially drug users, who recruited other partners with the same characteristics, to jointly participate in the peer health education program from wich peer workers came out. We did privileged acces interviews taking advantadge of the role played by peer workers who, due to their proximity to other mates and their status among them, enjoyed ready acces to target population and therefore were trained to carry out the interviews. The entire process concluded in January 2013.

The sample of participants included a total of 178 persons, all of whom were potential users of psychoactive substances serving sentence at Brians 1 
Prison. The study was evaluated, accepted and supervised by the Centre d'Estudis Jurídics $i$ Formació Especialitzada del Departament de Justícia la Generalitat de Catalunya (CEJFE) (Centre for Legal Studies and Specialist Training of the Department of Justice of the Regional Government of Catalonia). The ethical recommendations of the Helsinki Declaration were complied with ${ }^{20}$.

Different types of analysis were carried out on the answers given by the interviewees:

- Descriptive analysis of the main variables studied and comparisons of the proportions found there of the three outcome variables established via the Student $t$ test (for quantitative outcome variables), the Pearson chi-square test and the Fisher exact test (for categorical outcome variables).

- Univariate and multivariate logistic regression models to identify the variables associated with use of addictive substances and injected use in prison. In the case of the multivariate model, variables with a level of significance below 0.10 in the univariate model were included, and the odds ratios $(\mathrm{OR})$ and their respective confidence intervals (CI) of $95 \%$ were calculated.

Values with a $p$ value equal to or less than 0.05 were regarded as significant for all the analyses and the Statistical Package for the Social Sciences (SPSS) version 17 was used.

\section{RESULTS}

The main characteristics of the sample are described in Table 1. The average age of the participants was 36.8 years (standard deviation [SD]: 8.4). The average duration of their sentence was 8.6 years (SD of 6.5). Most of them were men (61.8\%) and Spanish (86\%). $74.7 \%$ of the participants acknowledged excessive use of addictive substances at some time in their lives, and $68 \%$ stated that they have followed a treatment for this problem. $75.8 \%$ declared that they had consumed drugs (tobacco and prescribed psychiatric drugs were excluded) in the last six months in prison, highlighting the use of cannabis $(64.6 \%)$, heroin $(50.0 \%)$, psychiatric drugs $(42.1 \%)$ of which $32 \%$ were without a prescription, and alcohol (8.4\%).

$33.7 \%$ admitted to presenting one or more STBBI: $27 \%$ were infected with HCV; $20.2 \%$ by HIV and $13.5 \%$ by both viruses. $18.5 \%$ stated that they had injected drugs in prison in the last six months. Of these, 54.5\% acknowledged that they had shared injection material, and $36.4 \%$ had participated in the NEP.
Table 2 shows the results of the univariate and multivariate analysis of the factors associated with drug use in prison in the last six months. The multivariate analysis shows that persons of Spanish nationality (AOR $=4.79$; CI 95\%: 1.52-15.16), recidivists $(\mathrm{AOR}=2.67$; CI 95\%: 1.11-6.46), who had received penalties $(\mathrm{AOR}=2.70$; CI 95\%: 1.18-6.22) and who had committed severe transgressions of coexistence while in prison (AOR=3,01; CI 95\%: 1.24-7.31), showed a higher likelihood of being involved in consumption of addictive substances in jail.

Table 3 shows that injecting drugs in prison is significantly related to the duration of the user's sentence $(\mathrm{AOR}=1.13$; CI 95\%: 1.05-1.23), having undergone addiction treatment $(\mathrm{AOR}=3.84$; CI 95\%: 0.95 $15.62)$ and being a carrier of STBBI $(\mathrm{AOR}=3.95$; $\mathrm{CI}$ 95\%: 1.42-10.98).

Table 4 on comparison of proportions shows that, amongst the intravenous drug users who exchanged needles (in the NEP), there was a significantly higher percentage of women $(66.7 \%$ compared to $16.7 \%)$ and of importance attributed to the treatment of health problems ( $90.9 \%$ compared to $50.0 \%)$, in the absence of differences in other potentially confusing variables referring to criminal behaviour and to consumption and health problems, in contrast to injectors who did not participate in NEPs.

\section{DISCUSSION}

The results of the survey match the data from previous studies on the most widely used substances in prison, which highlight depressors of the central nervous system (CNS) as the most suitable ones due to the specific limitations and needs of life in this environment ${ }^{3}$.

The participants of the study were characterised as a group with more severe issues tan the average incarcerated population in Catalonia with regard to criminal, penitenciary and health variables, such as sentence duration, levels of recidivism, excessive drug use in prison, the associated STBBI and health related risk practices of infection ${ }^{4,5}$. In fact, the high prevalence of health problems detected are similar to those obtained in samples of intravenous drug users (IDUs) attending harm reduction resources in the community ${ }^{21}$. One possible interpretation of this state of affairs is that the method applied has allowed us to effectively contact with groups of imprisoned persons who maintain a lifestyle that is marginalised with regard to institutional channels of rehabilitation and health promotion, highlighting the capacity of the 
Bañuls-Oncina E, Clua-García R, Imbernón Casas M, Jiménez-Vinaja R. Substance use characteristics, bealth risk practices and associated factors among people imprisoned in Catalonia: a cross-sectional study.

Table 1. Socio-demographic characteristics, criminal and prison conduct, use of addictive substances, risk behaviors and consumption related diseases of the population studied $(\mathrm{N}=178)$

\begin{tabular}{|c|c|c|}
\hline Variable & No. $(\%)^{*}$ & \\
\hline \multirow{2}{*}{ Sex } & Woman & $68(38.2)$ \\
\hline & Man & $110(61.8)$ \\
\hline \multirow{3}{*}{ Nationality } & Spanish & $153(86.0)$ \\
\hline & Foreign & $18(10.1)$ \\
\hline & Not available & $7(3.9)$ \\
\hline \multirow{4}{*}{$\begin{array}{l}\text { Main source of income } \\
\text { in prison }\end{array}$} & Work & $50(28.1)$ \\
\hline & External aid & $110(61.8)$ \\
\hline & Government support & $14(7.9)$ \\
\hline & Not available & $4(2.2)$ \\
\hline \multirow{3}{*}{ Sentences served } & Primary & $46(25.8)$ \\
\hline & Recidivist & $128(71.9)$ \\
\hline & Not available & $4(2.2)$ \\
\hline \multirow{3}{*}{ Penalties } & Penalised & $109(61.2)$ \\
\hline & Not penalised & $58(32.6)$ \\
\hline & Not available & $11(6.2)$ \\
\hline \multirow{3}{*}{ Severe transgressions } & Yes & $49(27.5)$ \\
\hline & $\mathrm{No}$ & $119(66.9)$ \\
\hline & Not available & $10(5.6)$ \\
\hline \multirow{2}{*}{$\begin{array}{l}\text { Acknowledged } \\
\text { addiction }\end{array}$} & Yes & $133(74.7)$ \\
\hline & No & $45(25.3)$ \\
\hline \multirow{3}{*}{$\begin{array}{l}\text { Consumption of drugs } \\
\text { in prison } \\
\text { in last } 6 \text { months }\end{array}$} & Yes & $135(75.8)$ \\
\hline & No & $40(22.5)$ \\
\hline & Not available & $3(1.7)$ \\
\hline \multirow{3}{*}{$\begin{array}{l}\text { Heroin in prison } \\
\text { in last } 6 \text { months }\end{array}$} & Yes & $89(50.0)$ \\
\hline & No & $85(47.8)$ \\
\hline & Not available & $4(2.2)$ \\
\hline \multirow{3}{*}{$\begin{array}{l}\text { Cocaine in prison } \\
\text { in last } 6 \text { months }\end{array}$} & Yes & $47(26.49)$ \\
\hline & No & $126(70.8)$ \\
\hline & Not available & $5(2.8)$ \\
\hline \multirow{3}{*}{$\begin{array}{l}\text { Cannabis in prison } \\
\text { in last } 6 \text { months }\end{array}$} & Yes & $115(64.6)$ \\
\hline & No & $59(33.1)$ \\
\hline & Not available & $4(2.3)$ \\
\hline \multirow{3}{*}{$\begin{array}{l}\text { Alcohol in prison } \\
\text { in last } 6 \text { months }\end{array}$} & Yes & $15(8.4)$ \\
\hline & No & $156(87.6)$ \\
\hline & Not available & $7(3.9)$ \\
\hline \multirow{3}{*}{$\begin{array}{l}\text { Psychiatric drugs } \\
\text { in prison in last } \\
6 \text { months }\end{array}$} & Yes & $75(42.1)$ \\
\hline & No & $97(54.5)$ \\
\hline & Not available & $6(3.4)$ \\
\hline \multirow{2}{*}{$\begin{array}{l}\text { Non-prescribed } \\
\text { psychiatric drugs in } \\
\text { prison in last } 6 \text { months } \\
(\mathrm{N}=75)\end{array}$} & Yes & $24(32)$ \\
\hline & No & $51(68)$ \\
\hline
\end{tabular}

\begin{tabular}{|c|c|c|}
\hline Variable & No. $(\%)^{*}$ & \\
\hline \multirow{3}{*}{$\begin{array}{l}\text { Consumption of } \\
\text { tobacco in prison } \\
\text { in last } 6 \text { months }\end{array}$} & Yes & $158(88.8)$ \\
\hline & No & $17(9.5)$ \\
\hline & Not available & $3(1.7)$ \\
\hline \multirow{3}{*}{ STBBI } & Yes & $60(33.7)$ \\
\hline & No & $92(51.7)$ \\
\hline & Not available & $26(14.6)$ \\
\hline \multirow{3}{*}{ HIV Carrier } & Yes & $36(20.2)$ \\
\hline & No & $123(69.1)$ \\
\hline & Not available & $19(10.7)$ \\
\hline \multirow{3}{*}{ HCV Carrier } & Yes & $48(27.0)$ \\
\hline & $\mathrm{No}$ & $106(54.5)$ \\
\hline & Not available & $24(13.5)$ \\
\hline \multirow{3}{*}{$\begin{array}{l}\text { Co-infection with } \\
\text { HIV-HCV }\end{array}$} & Yes & $24(13.5)$ \\
\hline & No & $139(78.1)$ \\
\hline & Not available & $15(8.4)$ \\
\hline \multirow{3}{*}{$\begin{array}{l}\text { Concern about health } \\
\text { problems }\end{array}$} & Yes & $110(61.8)$ \\
\hline & No & $66(37.6)$ \\
\hline & Not available & $2(1.1)$ \\
\hline \multirow{3}{*}{$\begin{array}{l}\text { Importance of } \\
\text { treatment for health } \\
\text { problems }\end{array}$} & Yes & $108(60.7)$ \\
\hline & No & $67(37.6)$ \\
\hline & Not available & $3(13.5)$ \\
\hline \multirow{2}{*}{$\begin{array}{l}\text { Treatment of drug } \\
\text { problems }\end{array}$} & Yes & $121(68.0)$ \\
\hline & No & $57(32.0)$ \\
\hline \multirow{3}{*}{$\begin{array}{l}\text { Injection in prison in } \\
\text { last } 6 \text { months }\end{array}$} & Yes & $33(18.5)$ \\
\hline & $\mathrm{No}$ & $141(79.2)$ \\
\hline & Not available & $4(2.2)$ \\
\hline \multirow{3}{*}{ Heroin $(\mathrm{N}=33)$} & Yes & $30(90.9)$ \\
\hline & No & $1(3.0)$ \\
\hline & Not available & $2(6.1)$ \\
\hline \multirow{3}{*}{ Cocaine $(\mathrm{N}=33)$} & Yes & $17(51.5)$ \\
\hline & No & $13(39.4)$ \\
\hline & Not available & $3(9.1)$ \\
\hline \multirow{3}{*}{$\begin{array}{l}\text { Participation in needle } \\
\text { exchange program } \\
(\mathrm{NEP})(\mathrm{N}=33)\end{array}$} & Yes & $12(36.4)$ \\
\hline & No & $18(54.5)$ \\
\hline & Not available & $3(9.1)$ \\
\hline \multirow{3}{*}{$\begin{array}{l}\text { Sharing injecting } \\
\text { equipment }(\mathrm{N}=33)\end{array}$} & Yes & $18(54.5)$ \\
\hline & No & $13(39.4)$ \\
\hline & Not available & $2(6.1)$ \\
\hline \multirow{3}{*}{$\begin{array}{l}\text { Tattooing } \\
\text { in prison }\end{array}$} & Yes & $82(46.1)$ \\
\hline & No & $92(51.7)$ \\
\hline & Not available & $4(7.2)$ \\
\hline
\end{tabular}


Bañuls-Oncina E, Clua-García R, Imbernón Casas M, Jiménez-Vinaja R. Substance use characteristics, bealth risk practices and associated factors among people imprisoned in Catalonia: a cross-sectional study.

Table 1. Socio-demographic characteristics, criminal and prison conduct, use of addictive substances, risk behaviors and consumption related diseases of the population studied $(\mathrm{N}=178)$ (continuation)

\begin{tabular}{lll}
\hline Variable & No. $(\%)^{*}$ & \\
\hline $\begin{array}{l}\text { Tattoing in high-risk } \\
\text { conditions }(\mathrm{N}=82)\end{array}$ & Yes & $43(52.4)$ \\
\cline { 2 - 3 } Unprotected sex & Yes & $39(47.6)$ \\
\cline { 2 - 3 } & No & $127(71.3)$ \\
\hline
\end{tabular}

Note. *Values calculated using the total $\mathrm{N}$ of the sample (178) as a basis, unless indicated otherwise.

STBBI: sexually transmitted and blood borne illness; HIV: immunodeficiency virus; $\mathrm{HCV}$ : hepatitis $\mathrm{C}$ virus.

applied research strategies to gain access to them and discover their needs.

The measurements related in some way to the severity of the criminal behaviour, such as recidivism, duration of the sentence and those of adaptation to prison regulations: penalties and severe transgressions of coexistence, are associated with the use of addictive substances and injecting drug use in prison, in the latter case, in combination with STBBI. Such data support data from the literature that suggest the existence of a sub-group of more serious consumers, what some authors call the "true addicts" 22 , who have a relationship with the substance that is notably different from that of other consumers, with fewer personal, social and economic resources, a higher level of psychiatric co-morbidity and associated consequences for physical health, and a more negative prognosis ${ }^{23,24}$. The proposed division would have implications in the subjects' criminal behaviour, since it has been suggested that underlying the relationship between drug dependence and crime there is a stratum of persistent criminal activity by a small number of consumer ${ }^{25}$ in whom negative indicators of health and recidivism coincide ${ }^{26}$.

The fact that having enrolled a treatment for drug problems does not protect against drug consumption

Table 2. Univariate and multivariate analyses of the factors linked to drug consumption over the last six months in prison

\begin{tabular}{|c|c|c|c|}
\hline Variable & Percentage of use $(\%)$ & OR (CI 95\%) & AOR (CI 95\%) \\
\hline \multicolumn{4}{|c|}{ Nationality } \\
\hline Foreign & 38.9 & 1 & 1 \\
\hline Spanish & 80.8 & $6.61(2.36-18.53)$ & $4.79(1.52-15.16)$ \\
\hline Age & & $0.98(0.94-1.02)$ & \\
\hline \multicolumn{4}{|l|}{ Sex } \\
\hline Female & 71.2 & 1 & \\
\hline Male & 80.7 & $1.69(0.83-3.46)$ & \\
\hline \multicolumn{4}{|l|}{ Recidivist } \\
\hline No & 61.4 & 1 & 1 \\
\hline Yes & 82.7 & $3.01(1.40-6.43)$ & $2.67(1.11-6.46)$ \\
\hline \multicolumn{4}{|c|}{ Severe transgressions } \\
\hline No & 73.1 & 1 & 1 \\
\hline Yes & 87.5 & $2.58(1.00-6.63)$ & $3.01(1.24-7.31)$ \\
\hline \multicolumn{4}{|l|}{ Penalties } \\
\hline No & 64.9 & 1 & 1 \\
\hline Yes & 82.4 & $2.53(1.21-5.28)$ & $2.70(1.18-6.22)$ \\
\hline \multicolumn{4}{|c|}{ Acknowledged addiction } \\
\hline No & 60.5 & 1 & \\
\hline Yes & 82.6 & $3.10(1.45-6.62)$ & \\
\hline \multicolumn{4}{|c|}{ Drug treatment } \\
\hline No & 66.1 & 1 & \\
\hline Yes & 82.4 & $2.40(1.16-4.96)$ & \\
\hline
\end{tabular}

Note. OR: odds ratio; CI: confidence interval; AOR: odds ratio adjusted by all the significant variables. 
Table 3. Univariate and multivariate analyses of the factors linked to injected consumption of substances in prison over the last six months

\begin{tabular}{|c|c|c|c|}
\hline Variable & $\begin{array}{l}\text { Percentage } \\
\text { of use }(\%)\end{array}$ & $\begin{array}{c}\text { OR } \\
(\mathrm{CI} 95 \%) \\
\end{array}$ & $\begin{array}{c}\text { AOR } \\
(\mathrm{CI} 95 \%)\end{array}$ \\
\hline \multicolumn{4}{|l|}{ Sex } \\
\hline Female & 17.6 & 1 & \\
\hline Male & 19.8 & $\begin{array}{c}1.15 \\
(0.53-2.53) \\
\end{array}$ & \\
\hline $\begin{array}{l}\text { Duration } \\
\text { of sentence }\end{array}$ & & $\begin{array}{c}1.07 \\
(1.01-1.13) \\
\end{array}$ & $\begin{array}{c}1.13 \\
(1.05-1.23) \\
\end{array}$ \\
\hline \multicolumn{4}{|c|}{ Main source of income } \\
\hline $\begin{array}{l}\text { Government } \\
\text { support }\end{array}$ & 28.6 & 1 & \\
\hline $\begin{array}{l}\text { Prison } \\
\text { allowance }\end{array}$ & 22.9 & $\begin{array}{c}0.74 \\
(0.22-2.58) \\
\end{array}$ & \\
\hline Work & 8.2 & $\begin{array}{c}0.22 \\
(0.05-1.04) \\
\end{array}$ & \\
\hline \multicolumn{4}{|c|}{ Severe transgressions } \\
\hline No & 14.7 & 1 & \\
\hline Yes & 22.4 & $\begin{array}{c}1.69 \\
(0.72-3.93)\end{array}$ & \\
\hline \multicolumn{4}{|l|}{ Drug treatment } \\
\hline $\mathrm{No}$ & 7.3 & 1 & 1 \\
\hline Yes & 24.4 & $\begin{array}{c}4.11 \\
(1.37-12.35) \\
\end{array}$ & $\begin{array}{c}3.84 \\
(0.95-15.62)\end{array}$ \\
\hline \multicolumn{4}{|l|}{ STBBI } \\
\hline No & 11.1 & 1 & 1 \\
\hline Yes & 33,9 & $\begin{array}{c}4,10 \\
(1,75-9,60) \\
\end{array}$ & $\begin{array}{c}3,95 \\
(1,42-10,98)\end{array}$ \\
\hline
\end{tabular}

Note. STBBI: sexually transmitted or blood borne illness; OR: odds ratio; $\mathrm{CI}$ : confidence interval; AOR: odds ratio adjusted by all the significant variables.

and injecting drug use in prison, becoming in the latter case a risk factor, confirms the data in other scientific publications about the existence of a worse prognosis for persons with substance addiction who have undergone treatment than those who have not ${ }^{19,20}$. This would indicate that treatment in itself does not necessarily involve any change and shifts the focus of attention towards effective treatment conditions of persons with substance use disorders (SUD) that, in a prison context, would be related to the combination of a pharmacological and psycho-social treatment ${ }^{24}$, the individualisation and management of specific circumstances that influence a person's specific behaviours ${ }^{27}$ and the continuation of monitoring in the community ${ }^{24}$.
Table 4. Variables that have shown a relation with the needle exchange program (NEP) in those users who have acknowledged that they inject drugs*

\begin{tabular}{|c|c|c|c|}
\hline Variable & $\begin{array}{l}\text { NEP } \\
(\mathrm{X})\end{array}$ & $\begin{array}{c}\text { Non } \\
\operatorname{NEP}(\mathrm{X})\end{array}$ & $\mathrm{p}$ value $\dagger$ \\
\hline Average age (in years) & 38.92 & 39.12 & 0.947 \\
\hline $\begin{array}{l}\text { Average duration } \\
\text { of sentence (in years) }\end{array}$ & 7.91 & 12.54 & 0.158 \\
\hline Recidivist (\%) & 66.7 & 88.9 & 0.189 \\
\hline Penalties (\%) & 87.5 & 64.7 & 0.362 \\
\hline Severe transgressions (\%) & 42.9 & 44.4 & 1.000 \\
\hline Sex (women) (\%) & 66.7 & 16.7 & $0.009+$ \\
\hline Work (\%) & 25.0 & 30.3 & 0.780 \\
\hline Family links (\%) & 75.0 & 94.4 & 0.274 \\
\hline $\begin{array}{l}\text { Concern about family } \\
\text { issues }(\%)\end{array}$ & 83.3 & 77.8 & 1.000 \\
\hline $\begin{array}{l}\text { Acknowledged } \\
\text { addiction }(\%)\end{array}$ & 75.0 & 77.8 & 1.000 \\
\hline Heroin consumption* $(\%)$ & 100 & 94.4 & 1.000 \\
\hline Cocaine consumption $*(\%)$ & 44.4 & 61.1 & 0.448 \\
\hline Sharing needles (\%) & 45.5 & 72.2 & 0.149 \\
\hline STBBI $(\%)$ & 60.0 & 76.5 & 0.415 \\
\hline $\begin{array}{l}\text { Treatment of drug } \\
\text { problems (\%) }\end{array}$ & 100.0 & 83.3 & 0.225 \\
\hline $\begin{array}{l}\text { Concerned about } \\
\text { health problems (\%) }\end{array}$ & 81.8 & 55.6 & 0.234 \\
\hline $\begin{array}{l}\text { Importance of treatment } \\
\text { for health problems }(\%)\end{array}$ & 90.9 & 50.0 & $0.044 \div$ \\
\hline
\end{tabular}

Note. "In prison, in the last six months; $\uparrow$ t tests for continuous variables, chi-squared test and Fisher exact test for categorical variables; $\ddagger$ statistically significant differences ( $\mathrm{p} \leq 0.05)$.

STBBI: sexually transmitted and blood borne illness.

The results of the study indicate that health risk practices persist in prisons, both in terms of the use of addictive substances and other unrelated activities. IDUs involved in NEPs are mostly women, they give more importance to treating health problems, in the absence of other differences regarding criminal behaviours, consumption or health, and they continue to share material. The differences between sexes confirms the greater interest ${ }^{24}$ and sensitivity ${ }^{28}$, already mentioned in other publications, of women inmates to care measures directed towards them, especialy in the relational field. The other data about the use of NEPs amongst injectors indicates that there is a margin of growth of harm reduction interventions and of deepening them to enhance their influence over users' 
behavior. In this regard, it is worthwhile highlighting the efforts to increase the coverage of NEPs, to synchronise them with harm reduction programs, such as substitution programs for opiate dependents, anti-retroviral therapy (ART) and the distribution of condoms, as well as complementing them with other effective Psychosocial approaches?. What should be outlined in the latter of these approaches is the value of educational peer interventions, which are especially beneficial for giving information about risk behaviours for infection from STBBIs, promoting changes in beliefs and attitudes (both of imprisoned users and of "expert" co-workers) and to reduce risk behaviours, as long as they are accompanied by access to hygienic consumption materials and condoms ${ }^{9}$; and of confering the user a leading role in the change process $^{29}$.

The study's limitations include the use of the selfreport ${ }^{26,30}$, of a non-random sample, and the fact that the participants did not answer in the same proportion to each question in the survey, which have to do ultimately with the influence of the interviewer's characteristics in the answers obtained and to the difficulties of the peer workers in managing their dual role of users and experts ${ }^{15}$. It would be recommendable in this case to increase the efforts made to prepare the interview and support the peer collaborators with the role conflicts associated with such a task. The proposal has been made to create support groups for peer workers, and to convert them into facilitators for access to members of the target population who would be interviewed by professionals ${ }^{15}$.

In any case, the limitations should be taken into consideration when making any appraisals based on the study data. The multivariate methodology and special sampling techniques for hidden populations are compensatory strategies to back up the validity of the results obtained.

Above and beyond the restrictions, the study provides data that suggests that there is use of drugs, injecting consumption and risk practices that can transmit STBBI in Catalonian prisons, despite the profusion of measures, primarily abstinence-based, geared towards suppressing them. It relates risk practices in prison with a marginalised lifestyle within the institution itself. It also provides arguments in favour of expanding and coordinating the range of interventions using an approach based on harm reduction, opening them up to peer methods and to psychological treatments that generally include the user's perspective ${ }^{12,31-33}$.

\section{ACKNOWLEDGEMENTS}

This study was financed with assistance from the Centre d'Estudis Jurídics i Formació Especialitzada del Departament de Justícia de la Generalitat de Catalunya (CEJFE) (Centre for Legal Studies and Specialist Training of the Department of Justice of the Regional Government of Catalonia) (D/480000100/2150). The authors would also like to thank all the participants, especially the peer workers, for their collaboration.

\section{CORRESPONDENCE}

Enric Bañuls Oncina

Centro Penitenciario Brians 1.

Sant Esteve Sesrovires. Barcelona.

E-mail: enricbanuls@gmail.com

\section{REFERENCES}

1. Vicens E, Tort V, Dueñas RM, Muro A, Pérez-Arnau F, Arroyo JM, et al. The prevalence of mental disorders in Spanish prisons. Crim Behav Ment Health. 2011;21:321-32.

2. Sander G, Murphy F. The furthest left behind: the urgent need to scale up harm reduction in prisons. Int J Prison Health. 2017;13:185-91.

3. Plan Nacional sobre Drogas. Encuesta sobre Salud y Consumo de Drogas a los Internados en Instituciones Penitenciarias (ESDIP). Madrid: Ministerio de Sanidad. Servicios Sociales e Igualdad; 2011.

4. Sander G, Scandurra A, Kamenska A, MacNamara C, Kalpaki C, Fernández Bessa C, et al. Overview of harm reduction in prisons in seven Europeran countries. Harm Reduct J. 2016;13:28.

5. Generalitat de Catalunya. Descriptors estadístics de serveis penitenciaris i rehabilitació. Departament de justícia. Direcció General de Serveis Penitenciaris. Àrea de Planificació i Estratègica; 2019 [Dades fins abril de 2019]. Disponible en: http://www.gencat.cat/justicia/estadistiques_serveis_penitenciaris/

6. Marco A, Saiz de la Hoya P, García-Guerrero J; grupo PREVALHEP. Estudio multicéntrico de Prevalencia de Infección por el VIH y factores asociados en las prisiones de España. Rev Esp Sanid Penit. 2012;14:19-27.

7. Hammett TM. HIV/AIDS and Other Infectious Disease Among Correctional Inmates: Transmi- 
sion, Burden and Apropiate Response. Am J Public Health. 2006;96:974-8.

8. Dumont DM, Brockmann B, Dickman S, Alexander N, Rich JD. Public Health and the Epidemic of Incarceration. Annu Rev Public Health. 2012;33:325-39.

9. Valera P, Chang Y, Lian Z. HIV risk inside U.S. prisons: a systematic review of risk reduction interventions conducted in U.S. prisons. AIDS Care. 2017;29:943-52.

10. Marlatt GA, Witkiewitz K. Update on harm-reduction policy and intervention research. Annu Rev Clin Psychol. 2010;6:591-606.

11. Tatarsky A, Marlatt GA. State of the art in harm reduction psychotherapy: an emerging treatment for substance misuse. J Clin Psychol. 2010;66:117-22.

12. Logan DE, Marlatt GA. Harm Reduction Therapy: a Practice-Friendly Review of Research. J Clin Psychol. 2010;66:201-14.

13. Clua R, Tenza G, Mingueza J. Guia de bones pràctiques en els programes d'intercanvi de xeringues. Barcelona: Agència de Salut Pública de Catalunya; 2015.

14. Kolind T, Duke K. Drugs in prisons: Exploring use, control, treatment and policy. Drugs: Education, Prevention and Policy. 2016;23:89-92.

15. Elliott E, Watson AJ, Harries U. Harnessing expertise: involving peer interviewers in qualitative research with hard-to-reach populations. Health Expect. 2002;5:172-8.

16. Dunn J, Ferri CP. Epidemiological methods for research with drug misusers: review of methods for studiyng prevalence and morbidity. Rev Saude Publica. 1999;33:206-15.

17. Shaghahi A, Bhopal RS, Sheikh A. Approaches to Recruiting 'Hard-To-Reach' Populations into Research: A Review of the Literature. Health Promot Perspect. 2011;1:86-94.

18. Goosdeel A. Euro Boule de neige: manuel méthodologique. Bruxelles. Modus Vivendi; 1999.

19. García Lalinde G, Gutiérrez Hernanz E, Morante Saboya L. Bola de nieve. Guía para la formación de usuarios/as de drogas como agentes de salud. Madrid. Grupo GID. Ministerio de Sanidad y Consumo; 2004.

20. World Medical Association. World Medical Association Declaration of Helsinki: ethical principles for medical research involving human subjects. JAMA. 2013;310:2191-4.
21. Folch C, Casabona J, Brugal MT, Majó X, Meroño $\mathrm{M}$, Espelt A, et al. Perfil de los usuarios de drogas por vía parenteral que mantienen conductas de riesgo relacionadas con la inyección en $\mathrm{Ca}$ taluña. Gac Sanit. 2012;26:37-44.

22. Heyman GM. Quitting drugs: quantitative and qualitative features. Annu Rev Clin Psychol. 2013;9:29-59.

23. Heather N. Is the concept of compulsión useful in the explanation or decription of addictive behaviour and experience? Addict Behav Rep. 2017;6:15-38.

24. Fazel S, Hayes AJ, Bartellas K, Clerici M, Trestman R. Mental health of prisoners: prevalence, adverse outcomes, and interventions. Lancet Psychiatry. 2016;3:871-81.

25. Silva TC, Vallejo F, Fernández D, Ruiz S, Ambrós M, Vallés N. Conflicto social en jóvenes consumidores de heroína. [Internet]. Boletín Criminológico. 2006;85:1-4. Disponible en: http://www. boletincriminologico.uma.es/boletines/85.pdf

26. Redondo Illescas S. El origen de los delitos: introducción al estudio y explicación de la criminalidad. Valencia: Tirant Humanidades; 2015.

27. McMurran M. What Works in substance misuse treatment for offenders? Crim Behav Ment Health. 2007;17:225-33.

28. Johnson JE. Integrating psychotherapy research with public health and public policy goals for incarcerated women and other vulnerable populations. Psychother Res. 2014;24:229-39.

29. Hunt G, Barker JC. Drug treatment in contemporary anthropology and sociology. Eur Addict Res. 1999;5:126-32.

30. Ledgerwood DM, Golderberger BA, Risk NK, Lewis CE, Price RK. Comparison betwen selfreport and hair analysis of illicit drug use in a community simple of middle-aged men. Addict Behav. 2008;33:1131-9.

31. Denning P. Little J. Over the influence: the harm reduction guide for managing drugs and alcohol. Second ediction. New York: The Guilford Press; 2017.

32. Orford J. Addicion as excessive appetite. Addiction. 2001;96:15-31.

33. Ward T, Mann RE, Gannon TA. The Good Lives Model of offender rehabilitation: Clinical implications. Aggression and Violent Behavior. 2007;12:87-107. 